\title{
Effect of Carbon Filter Usage Period on the Secondary Emission of Bioaerosols
}

\author{
Andrzej Berg ${ }^{1 *}$, Malgorzata Michalska², Maciej Tankiewicz1, Andrzej Staniszewski \\ Joanna Ratajczyk ${ }^{1}$, Lidia Wolska ${ }^{1}$ \\ ${ }^{1}$ Medical University of Gdańsk, Faculty of Health Sciences with the Institute \\ of Maritime and Tropical Medicine, Department of Environmental Toxicology, Gdańsk, Poland \\ ${ }^{2}$ Medical University of Gdańsk, Faculty of Health Sciences with the Institute \\ of Maritime and Tropical Medicine, Department of Immunology and Environmental Microbiology, Gdańsk, Poland \\ ${ }^{3}$ BIOPRO Sp. z o.o., Gdańsk, Poland
}

Received: 27 September 2019

Accepted: 16 October 2019

\begin{abstract}
Increased concentrations of bacteria and fungi in the air at the waste sorting plants and landfills pose health risks for employees as well as inhabitants of neighbouring areas. The current study presents the results of identification and quantification of the microorganisms present in the airflow leaving the carbon filters installed in the Solid Waste Utilization Plant in Pomeranian Voivodeship (Poland) in order to remove the odorous compounds from the sorting halls. Volatile organic compounds VOCs were identified by the sorption method using the solid Tenax TA sorbent and analysed using a thermal desorption-gas chromatography-mass spectrometry system (TD-GC/MS). Before activating the system for neutralizing odours, VOC concentrations in the sorting hall remained at the level of $12.1-15.2 \mathrm{mg} / \mathrm{m}^{3}$ and after activation of the neutralization system total concentration of VOCs in the sorting hall decreased and after the period of six months was $4.3 \mathrm{mg} / \mathrm{m}^{3}$. The microbiological analyses included the following microorganisms: psychrophilic and mesophilic bacteria from the coli group (Enterobacteriaceae family) and Escherichia coli, mold fungi and yeasts-like, Mannitol-positive and negative Staphylococci. Six months after the activation of the neutralization system, a marginal increase in all the studied microbiological parameters was observed, with the highest increase in Mannitolpositive Staphylococcus strains.
\end{abstract}

Keywords: bioaerosols, VOC, bacteria, fungi, carbon filters, odour substances

\section{Introduction}

Communal waste generated in residential areas and partly in other places (workplace, preschools, schools,

*e-mail: andrzej.berg@gumed.edu.pl shopping centres, railway stations, airports, etc.) constitutes mixtures of food and its packages as well as materials used in households. The structure of waste depends on the year's seasons (seasonality), where huge amounts of compost materials are generated in the summer-autumn period and ash in the winter-spring season [1]. It usually takes a couple of days before this 
waste is utilized, and during this time especially food undergoes biodegradation processes. The household waste in the first stage is transferred to the sorting plants. During the sorting process several compounds are released into the air of the sorting halls, which belong to the group of volatile organic compounds (VOC). Among them methane, aromatic hydrocarbons (i.e., toluene, styrene, xylene), sulphur compounds (i.e., hydrogen sulphide, thiols), terpenes (i.e., $\alpha$-, $\beta$-pinene, d-limonene, camphene, 3-carene), amines, alcohols (butanol), aldehydes, ketones (e.g., acetic acid, butyric acid) and volatile fatty acids were identified [2-6]. Most of these substances belong to the group of odour active compounds (OAC) and some of them are toxic. The employees of the utilization plants are mostly exposed to these compounds (via respiration, skin absorption); however, the odours are also usually burdensome to nearby residents. Other sources of VOCs include the burning of fuels such as gas, wood and kerosene. VOCs can be released from road bitumens and caustic effluents from bitumen production [7, 8]. VOCs including volatile sulfur compounds (VCSs) can be released from ground tire rubber and ground tire rubber after reclamation [9]. The odorous compounds are usually accompanied by the presence of microorganisms (including pathogens) and their fragments, which form bioaerosols. Biological factors pose a very serious health hazard to humans as some of them have allergenic or toxic properties [10]. They include bacteria, fungi, viruses, protozoa and compounds excreted by microorganisms such as: endotoxins, exotoxins, glucans, metabolites of fungi, mycotoxins, and allergens [11-14]. Inhalation or ingestion is the main route of exposure to the spread of fungi and bacteria. Microbial volatile organic compounds (MVOCs) or decomposing volatile microbial products found in bioaerosols may contribute to the development of various diseases $[15$, 16]. Depending on the composition of the bioaerosol, it may cause simple irritations, allergic reactions and dangerous infectious diseases [10, 17]. The highest threat is posed by the components of bioaerosols transmitted by means of air-dust or air-droplet routes, which penetrate the human organism through the skin and mucous membranes and are ingested with food [18-20]. Fungi and bacteria are well-known allergens (e.g., Penicillium and Aspergillus) that can grow in many work environments (composting, municipal waste removal, etc.) $[15,21]$.

The problem of odour removal constitutes a topic of research conducted by several science centres proposing various technical and technological solutions. Fig. 1 presents the available and most common deodorization methods based on different physical and chemical phenomena. All of these methods have their advantages and disadvantages described in more detail [22-24], and some are still not fully assessed.

The main objective of this study was the identification and quantification of microorganisms present in the airflow leaving the carbon filters that were installed in the Solid Waste Utilization Plant localized in the Pomeranian region of Poland in order to remove the odorous compounds from the sorting halls and reduce environmental odorous emissions. Measuring and identifying the microorganisms took place after the installation of the carbon filters at the outlet air. Simultaneously, concentrations of VOCs and microorganisms in sorting halls were determined. This study was performed from November 2016 to January 2018 at the solid waste utilization plant in Pomeranian Voivodeship.

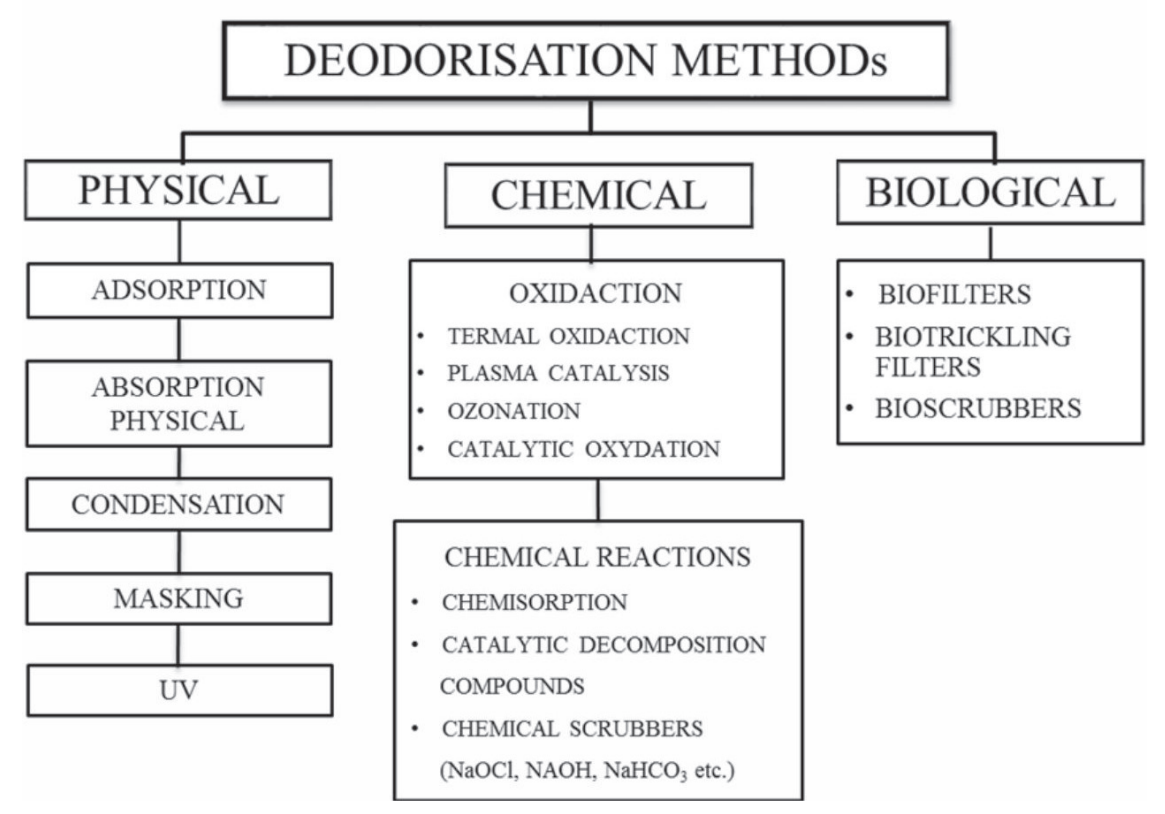

Fig. 1. Diagram of the most common deodorization methods. 


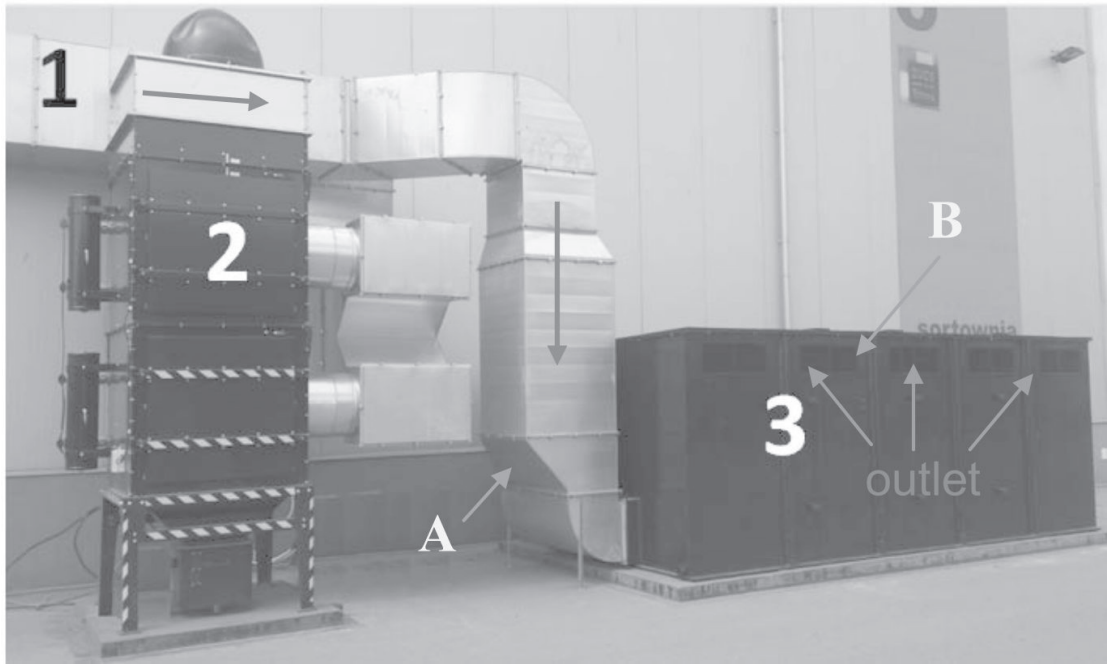

Fig. 2. Elements forming the neutralization system for the deodorization of air leaving the sorting hall with the direction of airflow: 1) ventilation canal used for the transportation of the airflow from the sorting hall, 2) cyclotron used for the removal of dust, and 3) neutralizer (container with the active carbon); locations of air sampling: A (air the coming carbon filters) and B (air leaving the carbon filters) (photo: A. Staniszewski).

\section{Materials and Methods}

\section{Materials}

As analytical standards the following chemicals were used: 1-bromo-4-fluorobenzene (purity 99.8\%), $0.25 \mathrm{~g}$, which was purchased in a solid form from $\mathrm{dr}$. Ehrenstorfer GMBH (Germany). Methanol for gas chromatography (purity $99.9 \%$ ) was purchased from Merck KGAA (Darmstadt, Germany). A glass TD sample tube $(1 / 4$ " $\times 90 \mathrm{~mm})$ filled with $130 \mathrm{mg}$ of Tenax TA (60-80 mesh) (Shimadzu, Japan) and capillary GC column Zebron (ZB-5ms), $30 \mathrm{~m}$ (length) : $0.25 \mathrm{~mm}$ (I.D.) : $0.25 \mu \mathrm{m}$ (film), Phenomenex, (Shim-pol, USA) was used.

\section{Instruments}

Thermal desorption system TD-20 (Shimadzu, japan) with sorbent Microtrap (Silcosteel tube 3.2-mm outer diameter $(2-\mathrm{mm}$ inner diameter $) \times 100 \mathrm{~mm}$, filled with $60 \mathrm{mg}$ Tenax TA) for refocusing of analytes prior to GC-MS analysis was used. GC-MS-QP 2010 ultra (Shimadzu, Japan).

Technical Description of the System Involved in the Neutralization of the Odorous Compounds

Locations of air sampling and the system used for the neutralization of the odorous compounds consists of three identical modules (N I, N II and N III) presented in Fig. 2. Arrangement of the ventilation in the sorting hall presented is Fig. 3. In one of the peripheral parts of the hall unsorted waste is delivered (the neutralization system III - this part is most-polluted and characterized by the largest odour emission), in the middle part (N II) and the second peripheral part (N I) sorting takes place. Both parts are separated by a curtain that is not sealed, and the task is to physically divide the hall in order to improve the air condition and working conditions.

\section{Determination of VOCs}

VOCs were determined by the sorption method using the $130 \mathrm{mg}$ of solid sorbent Tenax TA. $1.0 \mathrm{~L}$ and $0.6 \mathrm{~L}$ of air samples present in the sorting hall as well as $5.0 \mathrm{~L}$ of air samples subjected to neutralizer were collected. The samples were passed through glass tubes at the flow rate of $6.0 \mathrm{~L} / \mathrm{h}$. Then the tubes were closed with special caps and transported to the laboratory where on the same day they were analysed in the thermal desorption-gas chromatography-mass spectrometry system (TD-GC/MS). The quantitative method was developed in a laboratory. A quantitative determination of sum of VOC was carried using a single internal standard. 1-bromo-4-fluorobenzene (IS, $48.1 \mathrm{ng}$ in $2 \mu \mathrm{L}$ methanol) was added to each sorbent tube before the sampling process. All the concentrations are given in terms of added internal standard. According to literature data for Tenax TA, all quantified analytes have breakthrough volumes above the sampled air volume $[25,26]$. Repeatability of standard deviation for such determination of the sum of VOC was less than $10 \%$ and is comparable with those published in literature.

\section{Microbiological Studies}

Air samples were also analysed using the Koch sedimentation method, where Petri dishes of a given diameter containing specific medium for the bacteria and fungi (selective or nutrient agar) were 


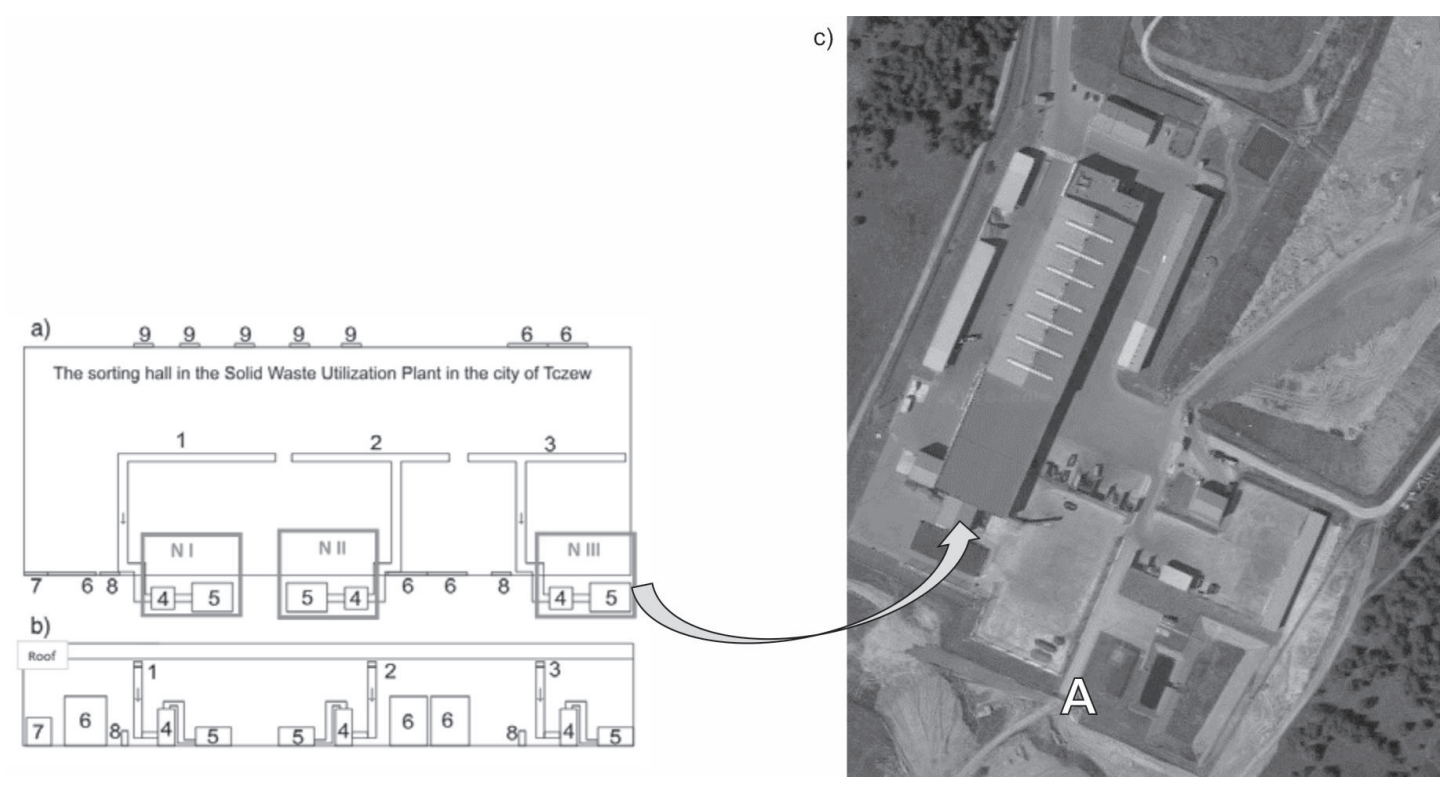

Fig. 3. Scheme of the ventilation in the sorting hall: a) view from the top, b) view from the side. 1. Ventilating canal of area number one, 2. Ventilating canal of area number two, 3. Ventilating canal of area number three, 4. Cyclotron used for the removal of dust, 5. Neutralizer (container with the active carbon), 6. Major entrance gate, 7. Minor entrance gate, 8. Entrance door, 9. Air-sucking device (fan), c) A- sampling point of the air masses flowing into the factory.

exposed for 5 to 10 minutes to the airflow in the sorting hall and leaving the carbon filters. After the incubation period of the samples, the total number of microorganisms in the air was determined using the Omelian formula expressed in the number of colony forming units (CFU) in $1 \mathrm{~m}^{3}$ of air. The microbiological analyses included the following microorganisms: psychrophilic and mesophilic bacteria from the coli group (Enterobacteriaceae family) and Escherichia coli, mold fungi and yeast-like, Mannitol-positive and negative Staphylococci. The total number of mesophilic bacteria was determined on trypticase soy agar (TSA) after incubation of the Petri dishes at $37^{\circ} \mathrm{C}$ for 24-48 hours. The total number of psychrophilic bacteria was also determined on the TSA, after the incubation of the Petri dishes at $22^{\circ} \mathrm{C}$ for 72 hours. The total number of Staphylococcus bacteria was determined in Chapman's medium after 24 hours incubation at $37^{\circ} \mathrm{C}$. Staphylococci were identified as Manitol positive or negative strains. The ability to produce coagulase was also analysed in the test with the lyophilised rabbit plasma. The total number of the coli group (Enterobacteriaceae family) and Escherichia coli were determined on Chromocult Agar after incubation of the Petri dishes at $37^{\circ} \mathrm{C}$ for $24-48$ hour. The total numbers of moulds and yeasts were determined on medium with chloramphenicol (YGC) after the incubation of the Petri dishes at $28^{\circ} \mathrm{C}$ for $7-10$ days.

The identification of fungi was carried out using the Nikon Eclipse E2000 microscope on the basis of macro and microscopic features which were compared with the atlas of airborne fungal spores in Europe [27]. All the media used in the microbiological studies were purchased at Merck (Germany).
Microbiological studies were carried out three times - on 14 July 2017, 24 October 2017 and 25 January 2018. The average air temperatures on these days were $14^{\circ} \mathrm{C}, 6^{\circ} \mathrm{C}$ and $6^{\circ} \mathrm{C}$, at relative humidity of $75 \%$, $99 \%$ and $93 \%$, respectively. Each time, control plates free of microbiological contaminants were also tested (unopened plates). In addition, on 25 January 2018, microbiological studies of the air masses flowing into the factory were performed (location of air sampling "A" in Fig. 3). The obtained results were similar to the results of the control, where traces of psychrophilic, mesophilic and Mannitol-negative Staphylococci and mold and yeast-like fungi were observed. Interpretation of the obtained results and microbiological assessment of the polluted air, according to the number of isolated microorganisms, was made on the basis of the Polish Standards (PN-Z-04111/02, 1989; PN-Z-04111/03, 1989). These standards currently do not apply, but so far have not been replaced by another document.

\section{Statistical Analysis}

Statistical analysis of obtained results was performed using Microsoft Excel 2010 (USA). Samples for testing microbiological parameters from the Solid Waste Utilization Plant were collected at different times after activation of the neutralization system. For VOC concentrations assessment samples were taken before starting the system, and during it working up to six months after system activation. Each sample collection period was performed in the same way. At each collection point after the carbon filters and at the sorting room samples were taken three times. To assess the effectiveness of the neutralization system 
the calculated mean values were used. For each sample point, standard deviations were calculated to check the repeatability of measurements.

\section{Results and Discussion}

\section{Characteristics of the VOCs}

The system for the neutralization of odours was activated on 14 July 2017. Before activation of the neutralization system, VOC concentration levels in the sorting hall were in the range of $12.1-15.2 \mathrm{mg} / \mathrm{m}^{3}$ (mean: $13.6 \mathrm{mg} / \mathrm{m}^{3}$ ) (Fig. 4). After its activation the total concentration of VOCs in the sorting hall decreased, and after a period of six months achieved level $4.3 \mathrm{mg} / \mathrm{m}^{3}$ (mean: $6.5 \mathrm{mg} / \mathrm{m}^{3}$; the summation of individually determined compounds yielded a total VOCs value). The total concentrations of VOCs were about 39, 25 and 6 times lower for neutralization systems I, II and III, respectively. The differences in the VOC concentrations before the system for odour neutralization activation and after that were statistically significant $(\mathrm{p}<0.05)$. In the VOC group, among others, the following compounds were identified: ethanol $\left(\mathrm{t}_{\mathrm{r}}=1.56 \mathrm{~min}\right)$, 1-methoxy-2-propanol and acetone $\left(t_{r}=1.68 \mathrm{~min}\right)$, acetic acid methyl ester $\left(t_{r}=2.41 \mathrm{~min}\right)$ and ethylbenzene $\left(\mathrm{t}_{\mathrm{r}}=7.50 \mathrm{~min}\right)$. Acetone was observed in the air in the coming carbon filters (air sampling a), while 1-methoxy-2-propanol was in the air leaving the carbon filters (air sampling b; Fig. 2). Acetone occurs on the concentrations of $0.004 \mathrm{mg} / \mathrm{m}^{3}$ (N I); $0.022 \mathrm{mg} / \mathrm{m}^{3}$ (N II); and $0.017 \mathrm{mg} / \mathrm{m}^{3}$ (N III). During the study, hydrogen sulphide and ammonia were also determined in the air of the sorting hall and at the outlet of the neutralizers using single-gas monitor GASBADGE pro (the European Standard EN50270 electromagnetic compatibility electrical apparatus for the detection and measurement of combustible gases, toxic gases or oxygen).

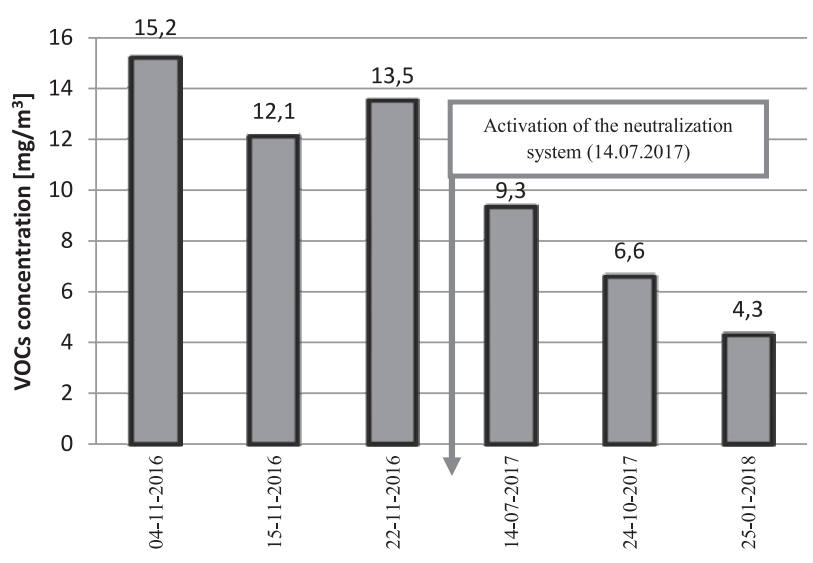

Fig. 4. Changes in the concentrations of VOCs in the applied chromatographic conditions.

\section{Characteristics of the Cultured Bacteria}

The results of this study show that the total number of the psychrophilic bacteria in the air in the sorting hall ranged from 3125 to $11250 \mathrm{CFU} / \mathrm{m}^{3}$. The total number of psychrophilic bacteria in the bioaerosol after the passage of air through neutralizer I ranged from 1574 to $2740 \mathrm{CFU} / \mathrm{m}^{3}$, after the passage through neutralizer II from 944 to $2646 \mathrm{CFU} / \mathrm{m}^{3}$, and after passage through neutralizer III ranged from 918 to $1858 \mathrm{CFU} / \mathrm{m}^{3}$. The total number of the mesophilic bacteria in the air in the sorting hall ranged from 1938 to $5180 \mathrm{CFU} / \mathrm{m}^{3}$. After the passage of the air through neutralizer I, the total number of mesophilic bacteria ranged from 1338 to $3540 \mathrm{CFU} / \mathrm{m}^{3}$, after the passage through neutralizer II ranged from 331 to $2457 \mathrm{CFU} / \mathrm{m}^{3}$, and after the passage through the neutralizer III ranged from 315 to $1638 \mathrm{CFU} / \mathrm{m}^{3}$. The number the Enterobacteriaceae family of bacteria in the air in the sorting hall ranged from 14 to $718 \mathrm{CFU} / \mathrm{m}^{3}$. The number of this bacteria in the bioaerosol after the passage of air through neutralizer I ranged from 0 to $158 \mathrm{CFU} / \mathrm{m}^{3}$, after passage through neutralizer II from 0 to $95 \mathrm{CFU} / \mathrm{m}^{3}$ and after passage through neutralizer III ranged from 0 to $7 \mathrm{CFU} / \mathrm{m}^{3}$. Including the number of Escherichia coli bacteria in the bioaerosol in the sorting hall ranged from 0 to $34 \mathrm{CFU} / \mathrm{m}^{3}$. After the passage through neutralizers I, II and III, the number of Escherichia coli bacteria ranged from 0 to $24 \mathrm{CFU} / \mathrm{m}^{3}$. The quantity of Mannitol-positive bacteria in the air samples from the sorting hall ranged from 94 to $307 \mathrm{CFU} / \mathrm{m}^{3}$ and the number of Mannitol-negative bacteria ranged from 188 to $384 \mathrm{CFU} / \mathrm{m}^{3}$. The number of this Mannitol-positive bacteria in the bioaerosol passing through the neutralizers I, II and III ranged from 158 to $881 \mathrm{CFU} / \mathrm{m}^{3}, 79$ to $763 \mathrm{CFU} / \mathrm{m}^{3}$ and 55 to $730 \mathrm{CFU} / \mathrm{m}^{3}$, respectively. The number of this Mannitol-negative bacteria in the bioaerosol after the passage of air through the N I ranged from 102 to $173 \mathrm{CFU} / \mathrm{m}^{3}$, after the passage through the $\mathrm{N}$ II from 70 to $173 \mathrm{CFU} / \mathrm{m}^{3}$ and after the passage through the N III ranged from 47 to $236 \mathrm{CFU} / \mathrm{m}^{3}$. Bacteria of the genus Pseudomonas spp. in the studied air were not isolated. Six months after the activation of the neutralization system, an increase in all the studied microbiological parameters was observed, with the highest increase in Mannitol-positive Staphylococcus strains (Fig. 5). In the air samples collected from the sorting hall, Mannitol-positive Staphylococcus (1.6\%) and Mannitol-negative Staphylococcus (3.8\%) - including Staphylococcus epidermidis (2.2\%) and Staphylococcus saprophyticus (1.6\%) - were isolated. From the air in the sorting hall the rods of the Enterobacteriaceae family (2.4\%), including the Escherichia coli species $(0.16 \%)$, were also isolated. The total number of psychrophilic bacteria isolated from the air in the sorting hall was $55.5 \%$ and the mesophilic bacteria $36.6 \%$. In the air samples exiting 

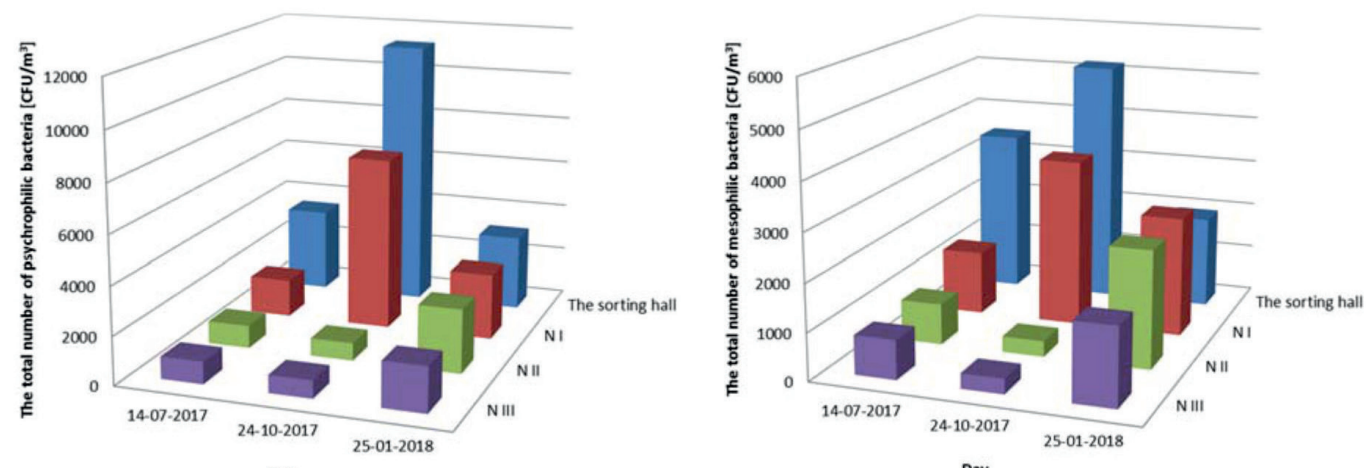

Day

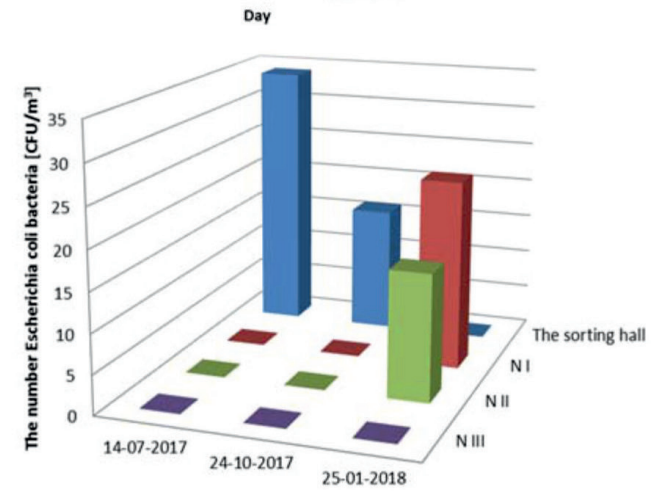

Day
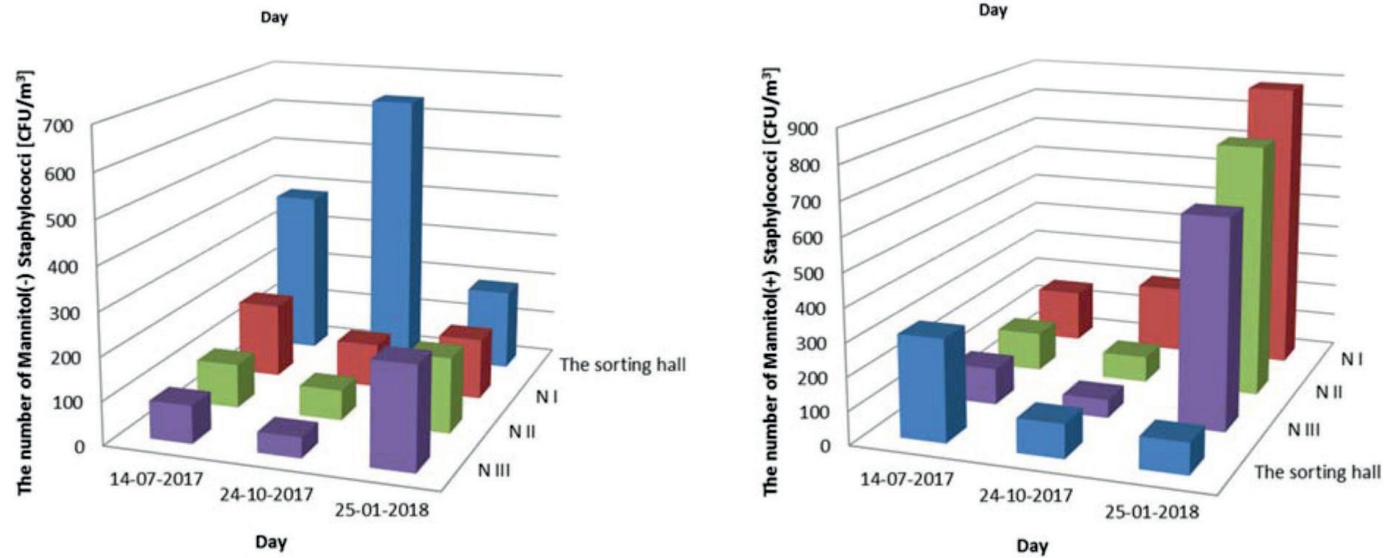

Fig. 5. Studied microbiological parameters (bacteria) during the research period.

carbon filters I, II and III (neutralizer), Mannitolpositive Staphylococcus (8.0\%) and Mannitol-negative Staphylococci (3.0\%), including Staphylococcus epidermidis $(2.0 \%)$ and Staphylococcus saprophyticus $(1.0 \%)$, were isolated. The rods of the Enterobacteriaceae family (0.8\%), including Escherichia coli $(0.1 \%)$ were also isolated. Bacteria of the Pseudomonas spp. genus in the studied air from the carbon filter neutralizer were not isolated. The total percentage of psychrophilic bacteria was $51.4 \%$ and the mesophilic bacteria $36.7 \%$. The analysis showed significant differences in the concentrations of bacterial aerosol between the sorting room and the system of odour neutralization (NI-NIII; Table 1). The concentrations of bacterial aerosol were higher in the indoor air than in air after the carbon filters, the differences were statistically significant $(p<0.05)$. Six months after the activation of the neutralization system, a marginal increase in all studied microbiological parameters was observed $(\mathrm{p}<0.05)$, with the highest increase in Mannitol-positive Staphylococcus strains (Table 2).

\section{Characteristics of the Cultured Fungi}

The quantity of mold and yeast-like fungi in the air samples from the sorting hall ranged from 273 to $2735 \mathrm{CFU} / \mathrm{m}^{3}$. The number of this fungi in the bioaerosol passing through neutralizers I, II and III ranged from 16 to $339 \mathrm{CFU} / \mathrm{m}^{3}, 17$ to $425 \mathrm{CFU} / \mathrm{m}^{3}$ and 8 to $245 \mathrm{CFU} / \mathrm{m}^{3}$, respectively (Fig. 6). From the collected air samples exiting carbon filters I, II, III (neutralizer) five species of mold fungi and one species of yeast Rhodotorula rubra $(0.3 \%)$ were isolated. The most frequently isolated mold fungi was Penicillium chrysogenum (89.5\%). Aspergillus niger (5.2\%), Aspergillus ochraceus (2.4\%) and Mucor mucedo (2.3\%) were less frequently isolated. The least frequent in the studied air was the mold fungus Alternaria alternata 

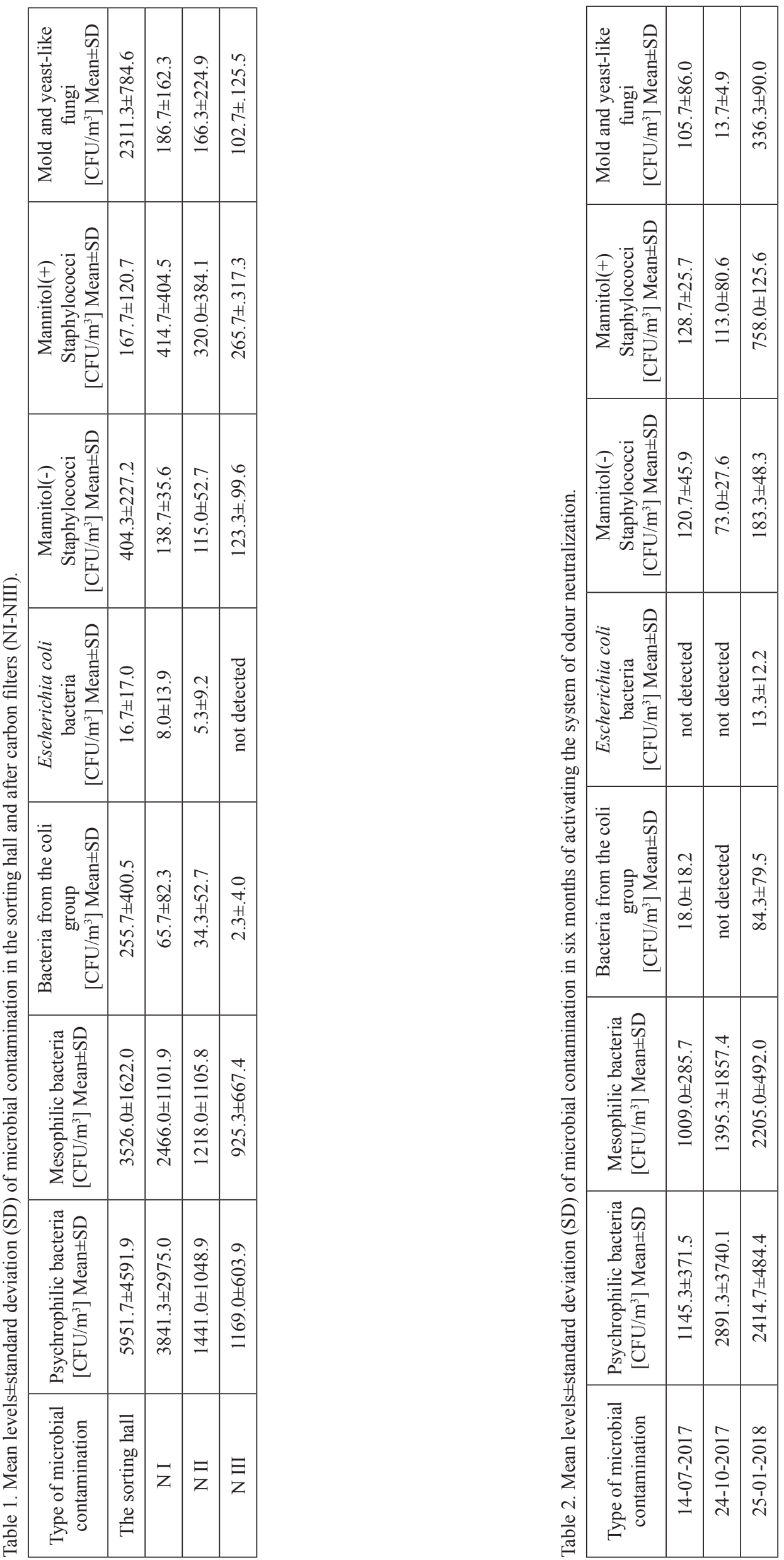


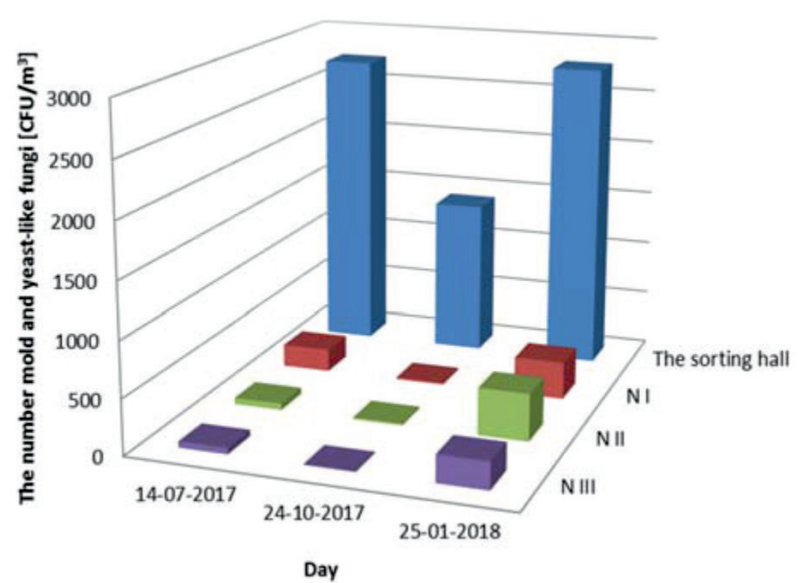

Fig. 6. Studied microbiological parameters (fungi) during the research period.
$(0.3 \%)$. Table 3 shows the number of mold fungi and yeast-like fungi $\mathrm{CFU} / \mathrm{m}^{3}$.

At present, there are no legal standards in Poland addressing the criteria and the normative values of the identification of microorganisms in polluted atmospheric air. There are also no world standards on the acceptable concentrations of biological contamination. In Poland the Interministerial Commission for Highest Concentration and Intensity of Agents Harmful to Health in the Working Environment proposes the acceptable concentrations of microorganisms in air at the level of $50000 \mathrm{CFU} / \mathrm{m}^{3}$ [28]. According to the World Health Organization (WHO), the acceptable value of microorganisms in air is $150 \mathrm{CFU} / \mathrm{m}^{3}$. Dutch experts believe that the fungal bioaerosol concentration over $10000 \mathrm{CFU} / \mathrm{m}^{3}$ becomes dangerous for human

Table 3. Numbers of mold fungi and yeast-like fungi $\mathrm{CFU} / \mathrm{m}^{3}$

\begin{tabular}{|c|c|c|c|c|c|c|}
\hline Study date & $\begin{array}{c}\text { Penicillium } \\
\text { chrysogenum }\end{array}$ & $\begin{array}{c}\text { Aspergillus } \\
\text { niger }\end{array}$ & $\begin{array}{c}\text { Aspergillus } \\
\text { ochraceus }\end{array}$ & Mucor mucedo & $\begin{array}{c}\text { Alternaria } \\
\text { alternat }\end{array}$ & $\begin{array}{c}\text { Rodotorhula } \\
\text { rubra }\end{array}$ \\
\hline 14.07 .2017 & 2846 & 142 & 0 & 64 & 0 & 0 \\
\hline 24.10 .2017 & 1140 & 125 & 165 & 8 & 0 & 0 \\
\hline 25.01 .2018 & 3437 & 166 & 32 & 119 & 24 & 24 \\
\hline Sum $\left[\mathrm{CFU} / \mathrm{m}^{3}\right]$ & 7423 & 433 & 197 & 191 & 24 & 24 \\
\hline$\%$ & 89.5 & 5.2 & 2.4 & 2.3 & 0.3 & 0.3 \\
\hline
\end{tabular}

Table 4. Identification bacteria occurring on the premises and in the vicinity of municipal waste landfill sites in different countries.

\begin{tabular}{|c|c|c|c|}
\hline Country & Location & Type of Bacteria & Ref. \\
\hline \multirow[t]{2}{*}{ Poland } & $\begin{array}{l}\text { Municipal landfills } \\
\text { in Sosnowiec }\end{array}$ & $\begin{array}{c}\text { Micrococcus spp., Pseudomonas aeruginosa, Corynebacterium } \\
\text { aquaticum, Staphylococcus xylosus, Staphylococcus sciuri, } \\
\text { Staphyloccus auricularis, Pasteurella haemolytica, Bacillus cereus, } \\
\text { Pseudomonas stutzeri, Rhodococcus spp., Sphingomonas } \\
\text { paucimobilis, Bacillus amyloliquefaciens, Corynebacterium } \\
\text { afermentans, Staphylococcus haemolyticus, }\end{array}$ & $\begin{array}{l}\text { Lis et al. } \\
2004[11]\end{array}$ \\
\hline & $\begin{array}{l}\text { Municipal Waste Disposal } \\
\text { Complex at Zolwin-Wypaleniska } \\
\text { near Bydgoszcz }\end{array}$ & $\begin{array}{l}\text { Pseudomonas fluorescens, Actinomycetes, Escherichia coli, } \\
\text { Salmonella spp., Enterococcus spp }\end{array}$ & $\begin{array}{l}\text { Breza-Boru- } \\
\text { ta } 2012[30]\end{array}$ \\
\hline Italy & $\begin{array}{l}\text { An open composting facility } \\
\text { flanked by a civil wastewater } \\
\text { treatment plant located in a rural } \\
\text { area of Northern Italy }\end{array}$ & $\begin{array}{l}\text { Mesophilic bacteria, psychrophilic bacteria, Pseudomonas spp., } \\
\text { Enterobacteriaceae, Clostridium spp. }\end{array}$ & $\begin{array}{c}\text { Grisoli et al. } \\
2009[12]\end{array}$ \\
\hline Denmark & $\begin{array}{l}\text { The waste in domestic areas in } \\
\text { Copenhagen and containers to the } \\
\text { trucks }\end{array}$ & $\begin{array}{l}\text { Acinetobacter spp., Bacillus spp., Cellulosimicrobium spp., } \\
\text { Microbacterium spp., Micrococcus spp., Staphylococcus spp., } \\
\text { Streptomyces spp. }\end{array}$ & $\begin{array}{l}\text { Madsen et } \\
\text { al. } 2016[14]\end{array}$ \\
\hline Korea & $\begin{array}{l}\text { Composting facility in Incheon } \\
\text { City }\end{array}$ & $\begin{array}{c}\text { Bacillus amyloliquefaciens, Bacillus cereus, Staphylococcus } \\
\text { lentus, Staphylococcus xylosus, Bacillus mycoides, Ochrobactrum } \\
\text { anthropi, Streptomyces rochei }\end{array}$ & $\begin{array}{c}\text { Byeon et al. } \\
2008[18]\end{array}$ \\
\hline India & $\begin{array}{l}\text { Municipal Solid Waste (MSW) } \\
\text { aerobic compost treatment plant in } \\
\text { Vidyaranyapuram Mysore city) }\end{array}$ & $\begin{array}{c}\text { Klebsiella spp., Pseudomonas spp., Staphylococcus aureus, } \\
\text { Enterobacter aerogenes, Salmonella, Bacillus sp., Escherichia coli, } \\
\text { Flavobacterium spp., Staphylococcus xylosus }\end{array}$ & $\begin{array}{l}\text { Shyamala et } \\
\text { al. } 2014[59]\end{array}$ \\
\hline Nigeria & $\begin{array}{l}\text { Municipal solid waste dumpsite in } \\
\text { Calabar metropolis }\end{array}$ & $\begin{array}{l}\text { Escherichia coli, Bacillus spp., Pseudomonas aeruginosa, } \\
\text { Enterobacter spp., Klebsiella spp., Proteus spp., Salmonella spp., } \\
\text { Staphylococcus aureus, Micrococcus luteus, Methanococcus spp. }\end{array}$ & $\begin{array}{l}\text { Bassey at al. } \\
2016[60]\end{array}$ \\
\hline
\end{tabular}


Table 5. Identification fungi occurring on the premises and in the vicinities of municipal waste landfill sites in different countries.

\begin{tabular}{|c|c|c|c|}
\hline Country & Location & Type of Fungi & Ref. \\
\hline \multirow[t]{2}{*}{ Poland } & $\begin{array}{l}\text { Municipal landfills } \\
\text { in Sosnowiec }\end{array}$ & $\begin{array}{c}\text { Cladosporium herbarum, Pink yeasts, White yeasts, Arthrographis } \\
\text { alba, Geotrichum candidum, Penicillium verrucosum, } \\
\text { Staphylotrichum coccosporum, Phoma sp., Alternaria alternate, } \\
\text { Cladosporium cladosporioides, Aspergillus niger, Myrothecium ver- } \\
\text { rucaria, Humicola insolens, Trichoderma koningii } \\
\text { Aspergillus alutaceus, Aspergillus flavus, Aspergillus fumigatus, } \\
\text { Fusarium dimerum Fusarium solani, Gliocladium roseum } \\
\text { Malbranchea sulfurea, Rhizomucor pusillus Thermoascus } \\
\text { crustaceus, Acremonium charticola, Aureobasidium pullulans, } \\
\text { Rhizopus rhizopodiformis }\end{array}$ & $\begin{array}{l}\text { Lis et al. } 2004 \\
\quad[11]\end{array}$ \\
\hline & $\begin{array}{l}\text { Municipal Waste Disposal Com- } \\
\text { plex at Zolwin-Wypaleniska near } \\
\text { Bydgoszcz }\end{array}$ & $\begin{array}{c}\text { Aspergillus Niger, Penicillium notatum, Rhizopus nigricans, } \\
\text { Rhizopus oryzae, Sclerotinia sclrotorium, Epicoccum nigrum, } \\
\text { Arthrinium phaespermum, Aspergillus fumigatus, Cladosporium } \\
\text { herbarium, Alternaria alternate }\end{array}$ & $\begin{array}{l}\text { Breza-Boruta } \\
2012[30]\end{array}$ \\
\hline Italy & $\begin{array}{l}\text { An open composting facility } \\
\text { flanked by a civil wastewater } \\
\text { treatment plant located in a rural } \\
\text { area of Northern Italy }\end{array}$ & $\begin{array}{l}\text { Alternaria alternata, Arthrinium phaeospermum, Aspergillus } \\
\text { chevalieri, Aspergillus clavato-nanica, Aspergillus flavus, } \\
\text { Aspergillus fumigatus, Aspergillus glaucus, Aspergillus nidulans, } \\
\text { Aspergillus niger, Aspergillus ochraeus, Aspergillus rescrictus, } \\
\text { Aspergillus ruber, Aspergillus sydowii, Aspergillus terreus, } \\
\text { Aspergillus thomii, Aureobasidiumpullulans, Cladosporium } \\
\text { cladosporioides, Cladosporium macrocarpum, Cladosporium } \\
\text { oxysporum, Doratomyces sp., Epicoccum nigrum, Fusarium } \\
\text { avenaceum, Fusarium lateritium, Fusarium poae, Fusarium } \\
\text { sambucinum, Fusarium solani, Fusarium subglutinans, Mucor spp., } \\
\text { Penicillium brevicompactum, Penicillium duclauxii, Penicillium } \\
\text { minioluteum, Penicillium olsonii, Penicillium purpurogenum, } \\
\text { Pseudorobillardaphragmitis, Rhizopus stolonifer, Scopulariopsis } \\
\text { brevicaulis, Trichodermaviride, Trichotheciumroseum }\end{array}$ & $\begin{array}{l}\text { Grisoli et al. } \\
2009[12]\end{array}$ \\
\hline Denmark & $\begin{array}{l}\text { The waste in domestic areas in } \\
\text { Copenhagen and containers to } \\
\text { the trucks }\end{array}$ & $\begin{array}{l}\text { Aspergillus glaucus, Aspergillus nidulans, Aspergillus niger, } \\
\text { Aspergillus versicolor, Cryptococcus magnus, Penicillinum } \\
\text { brevicaompactum, Penicillinum camemberti, Penicillinum } \\
\text { chrysogenum, Penicillinum commune, Penicillinum digitatum, } \\
\text { Penicillinum expansum, Penicillinum glabrum, Penicillinum itali- } \\
\text { cum, Penicillinum olsonii, Paecilomyces variotii, }\end{array}$ & $\begin{array}{l}\text { Madsen et al. } \\
2016[14]\end{array}$ \\
\hline Korea & $\begin{array}{l}\text { Composting facility in Incheon } \\
\text { City }\end{array}$ & $\begin{array}{l}\text { Pseudallescheria boydii, Aspergillus fumigatus, Chaetomium spp., } \\
\text { Penicillium spp., }\end{array}$ & $\begin{array}{l}\text { Byeon et al. } \\
2008[18]\end{array}$ \\
\hline India & $\begin{array}{l}\text { (Municipal Solid Waste (MSW) } \\
\text { aerobic compost treatment plant } \\
\text { in Vidyaranyapuram Mysore } \\
\text { city) }\end{array}$ & $\begin{array}{l}\text { Alternaria sp., Aspergillus niger, Aspergillus fumigates, Aspergillus } \\
\text { flavus, Aspergillus rapens, Fusarium, Mucor mucedo, Penicillium } \\
\text { sp., Rhizopus stolonifer, Trichoderma sp., Varicospo rium, }\end{array}$ & $\begin{array}{l}\text { Shyamala et } \\
\text { al. } 2014[59]\end{array}$ \\
\hline Nigeria & $\begin{array}{l}\text { Municipal solid waste dumpsite } \\
\text { in Calabar metropolis }\end{array}$ & $\begin{array}{c}\text { Candida albicans, Aspergillus sp., Saccharomyces sp., Candida } \\
\text { tropicalis, Penicillium sp., Candida parapsilosis }\end{array}$ & $\begin{array}{c}\text { Bassey et al. } \\
2016[60]\end{array}$ \\
\hline
\end{tabular}

health [29]. The authors of this study analysed the microbiological contamination of the atmospheric air based on: The Polish Standards (PN-89/Z-04111/02 and PN-89/Z-04111/03) and Report 12 of the CEC (Commission of the European Communities 1993). Indoor air quality and its impact on man. Biological particles in indoor environments. The average number of psychrophilic and mesophilic bacteria isolated from the air leaving the carbon filter was $2150 \mathrm{CFU} / \mathrm{m}^{3}$ and $1536 \mathrm{CFU} / \mathrm{m}^{3}$. The concentrations of these bacteria ranged from 1000 to 3000 bacteria in $1 \mathrm{~m}^{3}$, which according to the Polish Standard
PN-89Z-04111/02 is defined as moderately contaminated. According to the CEC, this was defined as highly and very highly contaminated. The average number of Mannitol-positive and Mannitolnegative Staphylococci bacteria in the sorting hall was $168 \mathrm{CFU} / \mathrm{m}^{3}$ and $333 \mathrm{CFU} / \mathrm{m}^{3}$, respectively, whereas the air leaving the carbon filters $630 \mathrm{CFU} / \mathrm{m}^{3}$ and $126 \mathrm{CFU} / \mathrm{m}^{3}$. The number of Mannitol-positive and Mannitol-negative Staphylococci exceeded acceptable values defined by the Polish Standard PN86/Z-04111/02. On 25 January 2018 the number of Mannitol-positive Staphylococci exceeded acceptable values by 35 times 
Table 6. Review of literature on the concentrations of bacteria and fungi in the outdoor air.

\begin{tabular}{|c|c|c|c|}
\hline Country & Location & Microorganisms concentration & Ref. \\
\hline \multirow{7}{*}{ Poland } & City Poznań & $\begin{array}{l}\text { Total bacteria max: } 13000 \mathrm{CFU} / \mathrm{m}^{3} \\
\text { Mold fungi max: } 9000-16000 \mathrm{CFU} / \mathrm{m}^{3}\end{array}$ & Bugajny et al. 2005 [33] \\
\hline & City Toruń & $\begin{array}{c}\text { Bacteria heterotrophic mesophilic mean: } 79-189 \mathrm{CFU} / \mathrm{m}^{3} \\
\text { Family Enterobacteriaceae mean: } 2-6 \mathrm{CFU} / \mathrm{m}^{3} \\
\text { Mold fungi mean: } 49-140 \mathrm{CFU} / \mathrm{m}^{3} \mathrm{U} \mathrm{m}^{-3}\end{array}$ & $\begin{array}{l}\text { Donderski et al. } 2004 \\
{[43]}\end{array}$ \\
\hline & City Bydgoszcz & $\begin{array}{c}\text { Bacteria heterotrophic mean: } 56-467 \mathrm{CFU} / \mathrm{m}^{3} \\
\text { Staphylococci mean: } 0-11 \mathrm{CFU} / \mathrm{m}^{3} \\
\text { Mold fungi mean: } 511-748 \mathrm{CFU} / \mathrm{m}^{3}\end{array}$ & $\begin{array}{l}\text { Małecka - Adamowicz et } \\
\text { al. } 2015 \text { [44] }\end{array}$ \\
\hline & City Kraków & $\begin{array}{l}\text { Bacteria heterotrophic mesophilic: } 11-327 \mathrm{CFU} / \mathrm{m}^{3} \\
\text { Staphylococci mean: } 10-69 \mathrm{CFU} / \mathrm{m}^{3}, \max : 863 \mathrm{CFU} / \mathrm{m}^{3} \\
\text { Mold fungi mean: } 226-111 \mathrm{CFU} / \mathrm{m}^{3}, \max 3447 \mathrm{CFU} / \mathrm{m}^{3}\end{array}$ & $\begin{array}{l}\text { Lenart-Boroń et al. } 2014 \\
\qquad[45]\end{array}$ \\
\hline & City Hel & $\begin{array}{c}\text { Bacteria heterotrophic mesophilic max: } 38 \mathrm{CFU} / \mathrm{m}^{3} \\
\text { Mold fungi max: } 600 \mathrm{CFU} / \mathrm{m}^{3}\end{array}$ & Marks et al. 2001 [46] \\
\hline & City Gdynia & $\begin{array}{l}\text { Total bacteria max: } 943 \mathrm{CFU} / \mathrm{m}^{3} \\
\text { Mold fungi max: } 266 \mathrm{CFU} / \mathrm{m}^{3}\end{array}$ & $\begin{array}{l}\text { Michalska et al. } 2010 \\
{[47]}\end{array}$ \\
\hline & City Sopot & $\begin{array}{l}\text { Total bacteria max: } 786 \mathrm{CFU} / \mathrm{m}^{3} \\
\text { Mold fungi max: } 2030 \mathrm{CFU} / \mathrm{m}^{3}\end{array}$ & $\begin{array}{l}\text { Michalska et al. } 2010 \\
{[47]}\end{array}$ \\
\hline Austria & City Graz & $\begin{array}{c}\text { Bacteria heterotrophic mesophilic: } 0-2500 \mathrm{CFU} / \mathrm{m}^{3} \\
\text { Xerophilic fungi: } 30-2300 \mathrm{CFU} / \mathrm{m}^{3}\end{array}$ & Haas et al. 2013 [38] \\
\hline Germany & $\begin{array}{l}\text { City Kassel residents near } \\
\text { compositing site }\end{array}$ & $\begin{array}{l}\text { Total bacteria: } 22000-510000 \mathrm{CFU} / \mathrm{m}^{3} \\
\text { Mold fungi: } 7700-130000 \mathrm{CFU} / \mathrm{m}^{3}\end{array}$ & Herr et al. 2003 [48] \\
\hline Spain & Murcia & $\begin{array}{l}\text { Total bacteria mean: } 144 \mathrm{CFU} / \mathrm{m}^{3} \\
\text { Mold fungi mean: } 388 \mathrm{CFU} / \mathrm{m}^{3}\end{array}$ & Soto et al. 2009 [49] \\
\hline Greece & Thessalonki & Total bacteria mean: $120000 \mathrm{CFU} / \mathrm{m}^{3}$ & $\begin{array}{l}\text { Genitsaris et al. } 2017 \\
{[50]}\end{array}$ \\
\hline Jordan & Al- Mafraq & $\begin{array}{l}\text { Total bacteria max: } 2055 \mathrm{CFU} / \mathrm{m}^{3} \\
\text { Mold fungi max: } 295 \mathrm{CFU} / \mathrm{m}^{3}\end{array}$ & Jacob et al. 2016 [51] \\
\hline \multirow{3}{*}{ China } & Coastal region Qingdao & Total microorganisms: $85000-166000 \mathrm{CFU} / \mathrm{m}^{3}$ & Li et al. $2011[52]$ \\
\hline & City Xian & Total microorganisms: $77000-1421000 \mathrm{CFU} / \mathrm{m}^{3}$ & Xie et al. 2018 [53] \\
\hline & City Beijing & Total bacteria: $71-22100 \mathrm{CFU} / \mathrm{m}^{-3}$, mean: $2217 \mathrm{CFU} / \mathrm{m}^{3}$ & Fang et al. 2007 [54] \\
\hline \multirow[b]{2}{*}{ USA } & City Cincinnati & Mold fungi: $0-3882 \mathrm{CFU} / \mathrm{m}^{3}$ & Lee et al. $2006[34]$ \\
\hline & New York City & $\begin{array}{l}\text { Total microorganisms onshore winds mean: } 580 \mathrm{CFU} / \mathrm{m}^{3} \\
\text { Total microorganisms offshore winds mean: } 778 \mathrm{CFU} / \mathrm{m}^{3}\end{array}$ & Montero et al. 2016 [55] \\
\hline Turkey & City Edirne & $\begin{array}{l}\text { Total bacteria: } 222-656 \mathrm{CFU} / \mathrm{m}^{3} \\
\text { Staphylococci: } 48-121 \mathrm{CFU} / \mathrm{m}^{3}\end{array}$ & Aydogdu et al. 2010 [56] \\
\hline \multirow{2}{*}{ India } & City Gwalior & $\begin{array}{l}\text { Total bacteria: } 9000 \mathrm{CFU} / \mathrm{m}^{3} \\
\text { Mold fungi: } 2600 \mathrm{CFU} / \mathrm{m}^{3}\end{array}$ & Yadav et al. 2015 [57] \\
\hline & $\begin{array}{l}\text { Maharashtra composting } \\
\text { facility near Mumbai }\end{array}$ & Total bacteria mean: $3800-54000 \mathrm{CFU} / \mathrm{m}^{3}$ & Pahari et al. 2016 [58] \\
\hline
\end{tabular}

and the number of Mannitol-negative Staphylococci by 5 times. High concentrations of Staphylococci bacteria can influence air quality and pose a potential environmental risk [30]. The quantitative analysis of the air leaving the carbon filters showed the presence of Enterobacteriaceae in the range of 0 to $158 \mathrm{CFU} / \mathrm{m}^{3}$. The number of Escherichia coli bacteria ranged 0 to $24 \mathrm{CFU} / \mathrm{m}^{3}$. Epidemiological studies on the Enterobacteriaceae family in the air show that the highest concentrations of these bacteria were in wastewater treatments and on municipal waste landfills
[31, 32]. Identified bacteria occurring on the premises and in the vicinity of the municipal waste landfill site in different countries are comparable (Table 4). Pseudomonas spp., Bacillus spp., Staphylococcus spp., the family Enterobacteriaceae were most frequently identified. The positive conclusion of these results is the lack of high contamination of yeast-like fungi of the air leaving the carbon filter. The average number of mold and yeast-like fungi in the air from the sorting hall were $2311 \mathrm{CFU} / \mathrm{m}^{3}$ and in the bioaerosol passing through the carbon filters was $152 \mathrm{CFU} / \mathrm{m}^{3}$. According to the 
Polish Standard PN-89Z-04111/03, air containing over $10000 \mathrm{CFU} / \mathrm{m}^{3}$ fungi poses a potential environmental risk. The concentrations of mold and yeast-like fungi in the air passing through the carbon filter points were relatively clean, and obtained values did not exceed $3000 \mathrm{CFU} / \mathrm{m}^{3}$, which according to the CEC is defined as moderately contaminated [33-35].

Identified fungi occurring on the premises and in the vicinity of the municipal waste landfill site in different countries are comparable (Table 5). The genus Aspergillus spp, Cladosporium spp, and Penicillium spp were most frequently identified.

A comparison of the number of microorganisms isolated from atmospheric air in different countries is presented in Table 6 . The above-mentioned studies show that there is a large range in the number of bacteria in the atmospheric air. When comparing the concentrations of microorganisms in different countries, it should be remembered that such a diverse number of microorganisms in the air is affected by the source of emissions, distance from it, its size, survival of microorganisms, meteorological conditions, year season and the amount of dust suspended in the air [36-39]. The Enterobacteriaceae family includes, along with many harmless symbionts, many of the more familiar pathogens, such as Salmonella and Escherichia coli. Most members of this family constitute the gut flora found in the intestines among humans and other animals. Some enterobacteria produce endotoxins and active biological lipopolysaccharides (LPS), which are found in the outer membrane of Gram-negative bacteria and are released after the destruction of the cell wall $[14,16]$. The most important effects of exposure to endotoxins are toxic pneumonitis (inhalation fever, organic dust toxic syndrome (ODTS), septic shock) $[31,40]$.

Data from the literature point to higher concentrations of bacteria and fungi in the atmospheric air at the sewage treatment plant and municipal waste utilization plants (Table 4) than in this study. When comparing the amount of bacterial and fungal bioaerosol contamination in the study with the recommended standards of air leaving the carbon filters (neutralizer), it should be remembered that even if the concentration was lower than the reference values under certain circumstances, potentially pathogenic microorganisms may cause health problems [29, 40]. There are still no epidemiological data defining the relationship between exposure to a risk factor and the health effect caused by its action [20]. Adsorption and colonization of microorganisms on activated carbon is poorly understood.

The study conducted by Le Pape et al. [41] shows that the use of silver in activated carbon fibers can have an bactericidal effect against Escherichia coli and Staphylococcus aureus, and also fungicidal properties. The use of silver together with activated carbon can be a promising air-cleaning method [42].

\section{Conclusion}

This work shows the results of studies on the microbiological contamination and VOC concentrations in the air of the Solid Waste Utilization Plant. The quality of inhaled air has a significant impact on health and well-being of employees as well as for the inhabitants of neighbouring areas. Data from several studies point to microorganisms, and their secondary metabolites may pose toxic effects on the human respiratory system. Therefore, increased amounts of bacteria and fungi in the air should be the basis for monitoring the level of microorganisms around recycling plants. The degree of exposure of organisms to compounds from the VOC group depends to a large extent on the length of exposure and levels of analyte content that is inhaled. Data from several studies also point to prolonged exposure to these compounds possibly leading to permanent damage to the liver, kidneys and nervous system. Therefore, the reduction of emissions of these compounds to the environment is mandatory.

There is still little information in the world's literature about the possibility of colonization by bacteria and mold and yeast-like fungi on active carbon, which in many installations is part of the odor neutralization system. These microorganisms may be a source of secondary bioaerosol emissions to the atmosphere. The obtained results of identification studies and quantitative analyses of the microorganisms presented in the air stream leaving the systems of the carbon filters confirmed that the neutralization system effectively eliminates the odours from the sorting room. The active carbon layers reduceed VOC concentrations in the air stream by up to $4.3 \mathrm{mg} / \mathrm{m}^{3}$, and at the same time decreased the concentration of odours in the sorting room. Six months after activating the neutralization system, an increase in all the studied microbiological parameters was observed. The highest increase in the number of Mannitol-positive Staphylococcus strains was detected, and the most frequently isolated mold fungi was Penicillium chrysogenum (89.5\%).

\section{Acknowledgements}

The authors thank the Solid Waste Utilization Plant in Pomeranian Voivodeship for its support.

\section{Conflict of Interest}

The authors declare no conflict of interest.

\section{References}

1. DENAFAS G., RUZGAS T., MARTUZEVICIUS D., SHMARIN S., HOFFMAN M., MYKHAYLENKO V., 
OGORODNIK S., ROMANOV M., NEGULYAEVA E., CHUSOV A., TURKADZE T., BOCHIOIDZE I., LUDWIG CH. Seasonal variation of municipal solid waste generation and composition in four East European cities. Resources, Conservation and Recycling 89, 22, 2010.

2. BRUNO P., CASELLI M., DE GENNARO G., SOLITO M., TUTINO M. Monitoring of odor compounds produced by solid waste treatment plants with diffusive samplers. Waste Manag. 27 (4), 539, 2007.

3. SCAGLIA B., ORZI V., ARTOLA A., FONT X., DAVOLI E., SANCHEZ A., ADANNI F. Odours and volatile organic compounds emitted from municipal solid waste at different stage of decomposition and relationship with biological stability. Bioresour. Technol. 102 (7), 4638, 2011.

4. FANG J.J., YANG N., CEN D.Y., SHAO L.M., HE P.J. Odor compounds from different sources of landfill: Characterization and source identification. Waste Manag. 32 (7), 1401, 2012.

5. TANI A., NOZOE S. Workplace concentrations and exposure assessment of monoterpenes in rosemary- and lavender-growing greenhouses. J. Occup. Health. 54, 459, 2012.

6. LEE H.D., JEON S.B., CHOI W.J., LEE S.S., LEE M.H., $\mathrm{OH}$ K.J. A novel assessment of odor sources using instrumental analysis combined with resident monitoring records for an industrial area in Korea. Atmos. Environ. 74, 277, 2013.

7. BOCZKAJ G., PRZYJAZNY A., KAMIŃSKI M. Characteristics of volatile organic compounds emission profiles from hot road bitumens. Chemosphere 107, 23, 2014.

8. BOCZKAJ G., PRZYJAZNY A., KAMIŃSKI M. New procedures for control of industrial effluents treatment processes. Ind. Eng. Chem. Res. 53, 1503, 2014.

9. GĄGOL M., BOCZKAJ G., HAPONIUK J.T., FORMELA $\mathrm{K}$. Investigation of volatile low molecular weight compounds formed during continuous reclaiming of ground tire. Polym. Degrad. Stabil. 119, 113, 2015.

10. GAUTAM S.P., BUNDELA P.S., PANDEY A.K., JAMALUDDIN, AWASTHI M.K., SARSAIYA S. Diversity of cellulolytic microbes and the biodegradation of municipal solid waste by a potential strain. Int. J. Microbiol. 2012, 1, 2012.

11. LIS D.O., ULFIG K., WLAZLO A., PASTUSZKA J.S. Microbial air quality in offices at municipal landfills. J. Occup. Environ. Hyg. 1 (2), 62, 2004.

12. GRISOLI P., RODOLFI M., VILLANI S., GRIGNANI E., COTTICA D., BERRI A., PICCO A.M., DACARRO C. Assessment of airborne microorganism contamination in an industrial area characterized by an open composting facility and a wastewater treatment plant. Environ. Res. 109 (2), 135, 2009.

13. ACHUDUME A.C., OLAWALE J.T. Enumeration and identification of gram negative bacteria present in soil underlying urban waste-sites in southwestern Nigeria. J. Environ. Biol. 31 (5), 643, 2010.

14. MADSEN A.M., ALWAN T., ORBERG A., UHRBRAND K., JORGENSEN M.B. Waste workers' exposure to airborne fungal and bacterial species in the truck cab and during waste collection. Ann. Occup. Hyg. 60, 651, 2016.

15. EDUARD W., HEEDERIK D., DUCHAINE C., GREEN B.J. Bioaerosol exposure assessment in the workplace: The past, present and recent advances. J. Environ. Monit. 14 (2), 334, 2012.
16. PEARSON C., LITTLEWOOD E., DOUGLAS P., ROBERTSON S., GANT T.W., HANSELL A.L. Exposures and health outcomes in relation to bioaerosol emissions from composting facilities: A systematic review of occupational and community studies. J. Toxicol. Environ. Health B 18 (1), 43, 2015.

17. GERBA C.P., TAMIMI A.H., PETTIGREW C., WEISBROD A.V., RAJAGOPALAN V. Sources of microbial pathogens in municipal solid waste landfills in the United States of America. Waste Manag. Res. 29 (8), 781, 2011.

18. BYEON J.H., PARK C.W., YOON K.Y., PARK J.H., HWANG J. Size distributions of total airborne particles and bioaerosols in a municipal composting facility. Bioresour. Technol. 99 (11), 5150, 2008.

19. NCUBE F., NCUBE E J., VOYI K. Bioaerosols, noise, and ultraviolet radiation exposures for municipal solid waste handlers. J. Environ. Public Health 2017, 1, 2017.

20. KIM K.H., KABIR E., JAHAN S.A. Airborne bioaerosols and their impact on human health. J. Environ. Sci. 67, 23, 2018.

21. DOUWES J., THORNE P., PEARCE N., HEEDERIK D. Bioaerosol health effects and exposure assessment: progress and prospects. Ann. Occup. Hyg. 47 (3), 187, 2003.

22. SCHLEGELMILCH M., STREESE J., STEGMANN R. Odour management and treatment technologies: An overview. Waste Manag. 25 (9), 928, 2005.

23. ESTRADA J.M., KRAAKMAN N.J., MUNOZ R., LEBRERO R. A comparative analysis of odour treatment technologies in wastewater treatment plants. Environ. Sci. Technol. 45 (3), 1100, 2011.

24. KIM K.H., SZULEJKO J.E., KUMAR P., KWON E.E., ADELODUN A.A., REDDY P.K. Air ionization as a control technology for off-gas emissions of volatile organic compounds. Environ. Pollut. 225, 729, 2017.

25. BROWN R.H, PURNELL C.J. Collection and analysis of trace organic vapor pollutants in ambient atmospheres: The performace of a Tenax-GC adsorbent tube. J. Chromatogr. A 178 (1), 79, 1979.

26. YAO C.C.D., ZLATKIS A. A new adsorbent for trace organic analysis in environmental samples. Chromatographia 23 (5), 370, 1987.

27. KÄÄRIK A., NILSSON S.T. Atlas of airborne fungal spores in europe. Berlin; New York: SpringerVerlag, 1983.

28. GÓRNY R.L., STOBNICKA A. Harmful biological agents - employees' health protection. Bezpieczeństwo Pracy: nauka i praktyka 4, 511, 2014.

29. KOZAJDA A., SOWIAK M., PIOTROWSKA M., SZADKOWSKA-STANCZYK I. Waste sorting plantsrecognition of exposure to biological agents. Med. Pr. 60, 483, 2009.

30. BREZA-BORUTA B. Bioaerosols of the municipal waste landfill site as a source of microbiological air pollution and health hazard. Ecol.Chem. Eng. A 19 (8), 851, 2012.

31. BREZA-BORUTA B. Emission of microorganisms by municipal landfill as a health risk factor. Proceedings of ECOpole 6, 617, 2012.

32. KAŹMIERCZUK M., BOJANOWICZ-BABLOK A. Bioaerosol concentration in the air surrounding municipal solid waste landfill. Environ. Protect. Nat. Resour. 25(2), 17, 2014.

33. BUGAJNY A., KNOPKIEWICZ M., PIOTRASZEWSKAPAJAZK A., SEKULSKA-STRYJAKOWSKA M., STACH A., FILIPIAK M. On the microbiological quality of 
the outdoor air in Poznan, Poland. Polish J. Environ. Stud. 14, 287, 2005.

34. LEE T., GRINSHPUN S.A., MARTUZEVICIUS D., ADHIKARI A., CRAWFORD C.M., REPONEN T. Culturability and concentration of indoor and outdoor airborne fungi in six single-family homes. Atmos. Environ. 40, 2902, 2006.

35. CERNA K., WITTLINGEROVA Z., ZIMOVA M., JANOVSKY Z. Exposure to airborne fungi during sorting of recyclable plastics in waste treatment facilities. Med. Pr. 68, 1, 2017.

36. SRIKANTH P., SUDHARSANAM S., STEINBERG R. Bio-aerosols in indoor environment: Composition, health effects and analysis. Indian J. Med. Microbiol. 26, 302, 2008.

37. FRACZZEK K., ROPEK D. Municipal waste dumps as the microbiological threat to the natural environment. Ecol. Chem. Eng. 18 (1), 93, 2011.

38. HAAS D., GALLER H., LUXNER J., ZARFEL C., BUZINA W., FRIEDL H., MARTH E., HABIB J., REINTHALER F.F. The concentrations of culturable microorganisms in relation to particulate matter in urban air. Atmos. Environ. 65, 215, 2013.

39. CHMIEL M., FRĄCZEK K., GRZYB J. The problems of microbiological air contamination monitoring. WodaŚrodowisko-Obszary Wiejskie 15, 49, 2015 [In Polish].

40. HALEEM KHAN A.A., MOHAN KARUPPAYIL S. Fungal pollution of indoor environments and its management. Saudi J. Biol. Sci. 19 (4), 405, 2012.

41. LE PAPE H., SOLANO-SERENA F., CONTINI P., DEVILLERS C., MAFTAH A., LEPRAT P. Evaluation of the anti-microbial properties of an activated carbon fibre supporting silver using a dynamic method. Carbon 40, 2947, 2002.

42. WANG K., JI Q., LI H., GUAN F., ZHANG D., FENG H., FAN H. Synthesis and antibacterial activity of silver@ carbon nanocomposites. J. Inorg. Biochem. 166, 64, 2017.

43. DONDERSKI W., WALCZAK M., PIETRZAK M. Microbiological contamination of air within the city of Toruń. Polish J. Environ. Stud. 14, 223, 2004.

44. MAŁECKA-ADAMOWICZ M., DONDERSKI W., KUBERA $€$. Microbial air contamination in the center and in the Fordon district of Bydgoszcz. Polish J. Natur. Sci. 30, 259, 2015.

45. LENART-BOROŃ A., JURASZEK K. Assessment of microbiological quality of air in the selected sites situated by the main roads of Kraków. Environ. Med. 17, 15, 2014.

46. MARKS R., KRUCZALAK K., JANKOWSKA K., MICHALSKA M. Bacteria and fungi in air over the Gulf of Gdansk and Baltic sea. J. Aero. Sci. 32 (2), 237, 2001.

47. MICHALSKA M., BARTOSZEWICZ M., CIESZYNSKA M., NOWACKI J. Bioaerosols on Tri-city (Gdansk-SopotGdynia) beaches. Int. Marit. Health 61, 41, 2010.
48. HERR C.E., ZUR NIEDEN A., JANKOFSKY M., STILIANAKIS N.I., BOEDEKER R.H., EIKMANN T.F. Effects of bioaerosol polluted outdoor air on airways of residents: A cross sectional study. Occup. Environ. Med. 60 (5), 336, 2003.

49. SOTO T., LOZANO M., VICENTE-SOLER J., CANSADO J., GACTO M. Microbiological survey of the aerial contamination in urban areas of the city of Murcia, Spain. Anales de Biología 31, 7, 2009.

50. GENITSARIS S., STEFANIDOU N., KATSIAPI M., KORMAS K.A., SOMMER U., MOUSTAKA-GOUNI M. Variability of airborne bacteria in an urban Mediterranean area (Thessaloniki, Greece). Atmos. Environ. 157, 101, 2017.

51. JACOB J.H., IRSHAID F.I., ALHALIB M.A. Estimation and identification of airborne bacteria and fungi inthe outdoor atmosphere of Al-Mafraq area, Jordan. Jordan J. Biol. Sci. 9 (1), 3, 2016.

52. LI M., QI J., ZHANG H., HUANG S., LI L., GAO D. Concentration and size distribution of bioaerosols in an outdoor environment in the Qingdao coastal region. Sci. Total Environ. 409 19), 3812, 2011.

53. XIE Z., LI Y., LU R., LI W., FAN C., LIU P., WANG J., WANG W. Characteristics of total airborne microbes at various air quality levels. J. Aeros. Sci. 116, 57, 2018.

54. FANG Z., OUYANG Z., ZHENG H., WANG X., HU L. Culturable airborne bacteria in outdoor environments in Beijing, China. Microb. Ecol. 54 (3), 487, 2007.

55. MONTERO A., DUEKER M.E., O'MULLAN G.D. Culturable bioaerosols along an urban waterfront are primarily associated with coarse particles. PeerJ 4, 1, 2016.

56. AYDOGDU H., ASAN A., TATMAN OTKUN M. Indoor and outdoor airborne bacteria in child day-care centers in Edirne City (Turkey), seasonal distribution and influence of meteorological factors. Environ. Monit. Assess. 164, 53, 2010.

57. YADAV J., KUMAR A., MAHOR P., GOEL A.K., CHAUDHARY H.S., YADAVA P.K., YADAV H., KUMAR P. Distribution of airborne microbes and antibiotic susceptibility pattern of bacteria during Gwalior trade fair, Central India. J. Formos. Med. Assoc. 114 (7), 639, 2015.

58. PAHARI A.K., DASGUPTA D., PATIL R.S., MUKHERJI S. Emission of bacterial bioaerosols from a composting facility in Maharashtra, India. Waste Manag. 53, 22, 2016.

59. SHYAMALA D.C., BELAGALI S.L. Seasonal variation of microbial populations during composting processes of municipal solid wastes. Int. J. Innovat. Res. Sci. Eng. Technol. 3, 14126, 2014.

60. BASSEY I.U., ODOKUMA L., ANDY I.E. Global warming potentials of municipal solid waste dumpsites in Calabar metropolis, cross river state. J. Geogr. Environ. Earth Sci. Int. 7 (1), 1, 2016. 
